\title{
EMBAJADAS Y CONSULADOS COMPARTIDOS. LA PRÁCTICA DE ESPAÑA EN LA UNIÓN EUROPEA Y EN LA COMUNIDAD IBEROAMERICANA
}

\author{
ANTONIO PASTOR PALOMAR'
}

\author{
Cómo citar/Citation \\ Pastor Palomar, A. (2016). Embajadas y consulados compartidos. \\ La práctica de España en la Unión Europea y en la Comunidad Iberoamericana. \\ Revista de Derecho Comunitario Europeo, 54, 517-554. \\ doi: http://dx.doi.org/10.18042/cepc/rdce.54.03
}

\section{Resumen}

El estudio abarca la red de embajadas y consulados compartidos entre España y varios Estados europeos o iberoamericanos, y entre España y delegaciones de la UE. Las Convenciones de 1961 y de 1963 constituyen el marco jurídico internacional de referencia, si bien puede sostenerse que existe un desarrollo progresivo del derecho. Además, España ha adoptado recientemente dos leyes, una, sobre la acción exterior del Estado, otra, sobre los tratados y otros acuerdos internacionales, que pueden promover nuevas formas de diplomacia como la colocación. Hasta el momento, la práctica no se ha hecho pública aunque la Administración española la haya declarado estratégica. En conclusión, se ha demostrado la necesidad de dar a conocer y de ordenar esta práctica realizada mediante acuerdos internacionales.

\section{Palabras clave}

Nueva diplomacia; compartición de recursos; acreditación múltiple; representación de intereses; colocación; intercambio de diplomáticos; protección consular; acuerdos administrativos; acuerdos no normativos.

Profesor titular de Derecho Internacional Público y Relaciones Internacionales, Universidad Rey Juan Carlos. Este trabajo se inserta dentro de un proyecto de investigación financiado por el Ministerio de Economía y Competitividad del que el autor es investigador (DER 2014-55484-P). 


\title{
SHARED EMBASSIES AND CONSULATES. SPAIN'S PRACTICE IN THE EUROPEAN UNION AND IN THE IBERO-AMERICAN COMMUNITY
}

\begin{abstract}
This paper is focused on the network of shared embassies and consulates between Spain and several European or Ibero-American States, as well as cases between Spain and EU delegations. The 1961 Convention and the 1963 Convention set the key international legal framework, and yet it can be stated that there is a progressive development of the law. Two Laws have recently been approved in Spain on foreign action and on treaties and other international agreements that can develop new forms of diplomacy, such as co-location. This practice has not yet been made public, although it has been declared of strategic interest by the Spanish Administration. In conclusion, it has been demonstrated the need to show and order this practice made up of international agreements.
\end{abstract}

\section{Key words}

New diplomacy; resource sharing; multiple accreditation; representation of interests; co-location; exchange of diplomats; consular protection; administrative agreements; non-binding agreements.

\section{AMBASSADES ET CONSULATS PARTAGÉS. LA PRATIQUE DE L'ESPAGNE DANS L'UNION EUROPÉENNE ET DANS LA COMMUNAUTÉ IBÉRO-AMÉRICAINE}

\section{Résumé}

Cette étude comprend les implantations communes du réseau d'ambassades et de consulats entre l'Espagne et diverses Etats européens et ibéro américains, ainsi qu'entre l'Espagne et les délégations de l'Union Européenne. Les Conventions de 1961 et de 1963 constituent le cadre juridique international de référence, et il y a aussi un développement progressif du droit. De surcroît, l'Espagne a récemment approuvée deux lois portant sur l'action extérieure et sur les traités et d'autres accords internationaux qui pourraient mener à des nouvelles formes de diplomatie, comme la co-localisation. Cette pratique n'a pas encore été publiée, si bien elle a été déclarée d'intérêt stratégique. En conclusion, il a été démontré qu'il est nécessaire de rendre public ainsi que de mettre de l'ordre dans la pratique des accords internationaux sur cette matière.

\section{Mots clés}

Nouvelle diplomatie; ressources partagées; accréditation multiple; représentation d'intérêts; co-localisation; échange de diplomates; protection consulaire; accords administrative ; accords non normatifs. 


\section{SUMARIO}

I. INTRODUCCIÓN. II. LAS VARIADAS FORMAS DE COMPARTICIÓN DIPLOMÁTICA DEL SERVICIO EXTERIOR DE ESPAÑA: 1. La acreditación conjunta; 2. La representación o protección de intereses; 3. Funciones consulares en terceros Estados y por cuenta de un tercer Estado; 4. El intercambio y la colocación de personal diplomático y consular. III. LAS CAUSAS DEL NACIMIENTO Y DESARROLLO DE ESTAS NUEVAS FORMAS DE DIPLOMACIA: 1. Las sinergias diplomáticas y económicas con socios privilegiados; 2. Nuevas leyes de España (LASE y LTOAI). Los casos regulados. IV. LOS CASOS DE LA PRÁCTICA DE ESPAÑA Y LA NATURALEZA DE LOS ACUERDOS: 1. En el marco de la Unión Europea y del espacio Schengen: A. Acuerdos de representación consular en materia de visados con Estados Schengen; B. Acuerdos de colocación en delegaciones de la UE; C. Acuerdos de colocación en misiones diplomáticas de los Estados miembros; D. Acuerdos de intercambio de diplomáticos en servicios centrales; 2. En la Comunidad Iberoamericana de Naciones: A. Acuerdos de colocación entre Estados; B. Otros acuerdos de cooperación diplomática general que incluyen la colocación. V. CONCLUSIONES. PROPUESTAS DE ACUERDOS MODELO.

\section{INTRODUCCIÓN}

La compartición de personal, funciones y locales por los servicios diplomáticos de los Estados y de las organizaciones internacionales, es un fenómeno de la cooperación internacional multiforme, general e histórico. Algunas de sus formas se codificaron en la Convenio sobre Relaciones Diplomáticas de 1961 (en adelante, Convenio de 1961), y en el Convenio sobre Relaciones Consulares de 1963 (Convenio de 1963). Otras formas de compartición tienen un origen y desarrollo más reciente.

En España esta práctica se produce en dos ámbitos geopolíticos concretos que poseen diferente grado de institucionalización: el de la Unión Europea (UE) y el de la Comunidad Iberoamericana de Naciones ${ }^{2}$. Los principios ins-

2 Debe entenderse los veintidós Estados (diecinueve americanos, España, Portugal y Andorra) que participan en las Conferencias o Cumbres Iberoamericanas de Jefes de Estado y de Gobierno. 
piradores en uno y otro ámbito son los mismos, como muestra la legislación española relevante, a la que luego se aludirá. Además, alguno de los acuerdos diplomáticos examinados tiene un origen iberoamericano que España replica en el marco de la UE.

El objetivo del presente trabajo no es el examen en profundidad de cada una de esas formas de diplomacia, sino la identificación de sus elementos comunes y distintivos, según se presentan en la evolución reciente de la práctica y en la legislación de España. La precisión conceptual del punto II permitirá realizar una valoración adecuada de los problemas jurídicos subyacentes a una práctica desordenada, partiendo en el punto III de las causas de su nacimiento y desarrollo, y siguiendo en el punto IV con una clasificación de los casos de la práctica española.

En este mismo punto IV se estudiará la instrumentación de estas formas de cooperación diplomática y consular en acuerdos de variada naturaleza, interestatales o entre un Estado y una organización internacional, así como en normas de organizaciones internacionales. Estos acuerdos y normas institucionales aportan elementos para un desarrollo progresivo del derecho internacional, al no estar previstos ni en los Convenios de 1961 y 1963, ni en ningún otro tratado general relevante. Por razón de la materia, el marco jurídico de referencia inexcusable para estos desarrollos está constituido por esos convenios junto al derecho internacional consuetudinario.

Se presta especial atención al derecho de la UE, junto a los acuerdos de España convencionales (tratados) y no convencionales (acuerdos internacionales administrativos y acuerdos internacionales no normativos).

Además, resulta muy relevante el derecho español, no sólo por los acuerdos interadministrativos de derecho interno celebrados en la materia, sino también por la base legal que ofrecen tres leyes de reciente adopción: la Ley 2/2014, de 25 de marzo, de la Acción y del Servicio Exterior del Estado (en adelante, LASE) 3 ; la Ley 25/2014, de 27 de noviembre, de Tratados y otros Acuerdos Internacionales (LTOAI) ${ }^{4}$, y la Ley 40/2015, de 1 de octubre, de Régimen Jurídico del Sector Público (LRJSP), cuyo art. 47.2.d. tiene por objeto los convenios interadministrativos de los sujetos de derecho internacional

3 BOE núm. 74, de 26 de marzo de 2014, p 26531. Corrección de errores en BOE núm. 117, de 14 de mayo de 2014, y BOE núm. 155, de 26 de junio de 2014.

4 BOE núm. 288, de 28 de noviembre de 2014, p. 96841. Véase, sobre los distintos tipos de acuerdos internacionales de España, la obra colectiva dirigida por Paz ANDRÉS SÁENZ DE SANTAMARÍA, Javier DÍEZ-HOCHLEITNER, José MARTÍN Y PÉREZ DE NANCLARES (dirs.), Comentarios a la Ley de Tratados y otros Acuerdos Internacionales, Thomson Reuters Civitas, Cizur Menor, 2015. 
sometidos al derecho interno de una de las partes, que también podrían servir para instrumentar este tipo de cooperación diplomática 5 .

Quedan fuera del objeto de estudio, por razones evidentes, los acuerdos o protocolos de colaboración de la Administración Central con las comunidades autónomas para la incorporación de oficinas de estas en los locales de las representaciones de España en el exterior.

La práctica de España no es uniforme y la aplicación de las disposiciones de la LASE a algunos de los supuestos más recientes, no ha sido pacífica entre los órganos consultivos del Estado competentes en la materia. La razón puede estar en la redacción descuidada y confusa de esas disposiciones ${ }^{7}$. Por otro lado, la mayoría de los instrumentos que vertebran la ejecución de esta cooperación diplomática y consular no se han publicado oficialmente, por el momento, a la espera de que se apliquen completamente las disposiciones de la LTOAI y de este modo se clarifique la práctica. En consecuencia, para tener conocimiento de estos instrumentos, hace falta escudriñar en los archivos de las unidades del Ministerio de Asuntos Exteriores y de Cooperación (MAEC) concernidas, principalmente: la Dirección General del Servicio Exterior, el In-

BOE núm. 236, de 2 de octubre de 2015, p. 89411.

6 El Informe Anual de Aplicación de la Estrategia de Acción Exterior 2015, MAEC, abril 2016, menciona la suscripción de diez protocolos, entre 2012 y 2014, con La Rioja, Valencia, Castilla-León, Galicia, Asturias, Navarra, Canarias, Extremadura, Aragón y Castilla La Mancha, además de seis convenios específicos para la concreción de los aspectos económicos de personal y de funcionamiento de la integración de las oficinas de las Comunidades Autónomas en la Representación Permanente de España ante la UE (La Rioja, Castilla-León, Asturias, Navarra, Castilla-La Mancha y Aragón); también, el convenio singularizado de cooperación entre el MAEC y la Junta de Extremadura para la integración de la Oficina de Extremadura en las dependencias de la Embajada de España en Lisboa, información disponible en www.exterories.gob.es

7 Entre los todavía escasos estudios y análisis de la LASE, uno de los primeros, de elocuente título, fue el de Juan Pablo DE LAIGLESIA, «La Ley de la Acción y del Servicio Exterior del Estado. Un intento fallido", Revista Española de Derecho Internacional, v. 67-1, 2015, pp. 317-321. También, se critica la discutible sistemática de la LASE en el trabajo de Javier A. GONZÁLEZ VEGA, «La protección de los derechos humanos en la reciente legislación española en materia de Derecho internacional: Reflexiones críticas en torno a la Ley 2/2014 de Acción Exterior y la Ley Orgánica 16/2015 de privilegios e inmunidades», Ordine Internazionale e Diritti Umani, 2016, pp. $263-$ 281, p. 268. Véase, igualmente, Natividad FERNÁNDEZ SOLA, «La Ley de Acción Exterior y del Servicio Exterior del Estado y el Servicio Europeo de Acción Exterior", XXVI Jornadas de la Asociación Española de Profesores de Derecho Internacional y Relaciones Internacionales: España y la Unión Europea en el orden internacional, Sevilla, 15 y 16 de octubre de 2015 (en prensa). 
troductor de Embajadores, la Dirección General de Españoles en el Exterior y de Asuntos Consulares y Migratorios, la División de Tratados internacionales y Acuerdos no Normativos y la Asesoría Jurídica Internacional. La opacidad de la práctica contrasta con su carácter estratégico y con la declaración contenida en el preámbulo de la LASE acerca de la «exigencia fundamental [...] de articular una acción exterior que resulte armónica con la PESC, así como con los fines del Servicio Europeo de Acción Exterior [...] una adecuada coordinación de la Acción Exterior de España con la de los Estados que integran la Comunidad Iberoamericana de Naciones».

En suma, el objetivo de este estudio es doble: por un lado, dar a conocer esta práctica sustentada en un material de difícil acceso público y que no cuenta con referencias formales (de ahí que se detalle y describa, sistemáticamente, el contenido de los acuerdos); por otro lado, se pretende aportar claridad jurídica en el análisis de la práctica de España, pues esta se presenta bastante errática y la regulación de la LASE que la fundamenta es confusa. En el punto $\mathrm{V}$, a modo de conclusiones, se proponen varias soluciones de técnica jurídica para la concepción, calificación y tramitación de los acuerdos que formalizan esta cooperación.

En efecto, en las disposiciones de la LASE no se identifican las distintas instituciones diplomáticas y consulares que, a continuación, se explican.

\section{LAS VARIADAS FORMAS DE COMPARTICIÓN DIPLOMÁTICA DEL SERVICIO EXTERIOR DE ESPAÑA}

\section{LA ACREDITACIÓN CONJUNTA}

El art. 6 del Convenio de 1961 regula la poco utilizada acreditación conjunta por parte de dos o más Estados ante un tercer Estado, de un mismo jefe de misión o de un mismo agente diplomático que no sea el jefe de misión ${ }^{8}$. Se requiere la notificación previa del Estado o Estados acreditantes y la no oposición del Estado receptor. Suele haber un Estado principal acreditante de

8 La doctrina especializada, señalando el escaso uso internacional de esta institución por los problemas que puede generar de conflicto de intereses y de culturas diplomáticas, de confidencialidad y de gestión de la copropiedad de los locales, pone el ejemplo del embajador acreditado conjuntamente en Israel en 1963 por parte de Níger, Alto Volta, Costa de Marfil y Dahomey. Véase, Jean SALMON, Manuel de Droit Diplomatique, Bruylant, Bruxelles, 1994, p. 155. 
su misión diplomática y uno o varios segundos Estados que acreditan como propio jefe de misión al diplomático del Estado principal?

Esta forma debe diferenciarse de la colocación y de la práctica consistente en la construcción de un mismo local o edificio para albergar, exclusivamente, dos o más misiones diplomáticas ${ }^{10}$. A falta de un ejemplo concerniente a España sobre este último supuesto, puede citarse la construcción de un mismo edificio en Dacca, Bangladesh, a partir de 2016, que sirva como locales de las embajadas de Francia y de Alemania ${ }^{11}$. No se trata del caso de un mismo embajador acreditado por los dos Estados, ni de una embajada franco-alemana, sino de dos embajadas de dos Estados soberanos, con sendos jefes de misión, que comparten un mismo local y servicios, conservando cada Estado su propia representación.

También, esta práctica se distingue de otro tipo de acreditación múltiple por la que un Estado acredita a una misma persona o misión ante dos o más Estados. Se verá al hilo del estudio de la colocación de diplomáticos en misiones de otros Estados o en delegaciones de la UE.

\section{LA REPRESENTACIÓN O PROTECCIÓN DE INTERESES}

Los arts. 45 y 46 del Convenio de 1961 se ocupan de la representación internacional o protección de intereses de un Estado, en el Estado receptor, por

9 Véase, sobre esta institución diplomática, el trabajo de Eduardo VILARIÑO PINTOS, Curso de Derecho Diplomático y Consular, Tecnos, Madrid, 2011, p. 225.

10 Esas diferencias, resultantes de la práctica, también se subrayan en el trabajo de David RIJKS y Richard WHITMAN, «European diplomatic representation in third countries: trends and options», en AA.VV., The EU Foreign Service: How to build a more effective common policy, European Policy Centre, November 2007, pp. 35-46, p. 40. Un ejemplo citado es el del edificio de Berlín compartido por los países nórdicos como local de sus embajadas en Alemania.

11 En virtud del Acuerdo Marco, de 12 de octubre de 2006, entre Francia y Alemania, relativo a las implantaciones comunes de misiones diplomáticas y oficinas consulares, en vigor desde el 3 de marzo de 2008, (JORF, 11-62, de 23 de marzo de 2008) disponible en http://www.ambafrance-bd.org/-Ambassade-franco-allemande- (consultado el 8.4.2016). El Acuerdo de 2006 se inspira y completa el Arreglo Administrativo, de 3 de julio de 1997, entre el Ministro de Asuntos Exteriores de la República Francesa y el Ministerio Federal de Asuntos Exteriores de la República Federal de Alemania relativo a la cooperación entre sus misiones diplomáticas en Cabo Verde. Ambos instrumentos internacionales citan su compromiso con el Convenio de 1961. A su vez, el Arreglo Administrativo se deriva del Tratado de 22 de enero de 1963 sobre cooperación franco-alemana. 
los servicios diplomáticos de otro Estado ${ }^{12}$. Solamente la primera de estas dos disposiciones está concebida para situaciones de crisis, como la ruptura de relaciones diplomáticas, la terminación y la suspensión de la misión diplomática. Con ocasión de la ruptura de relaciones bilaterales por el asalto a la Embajada española en Ciudad de Guatemala por las fuerzas de seguridad guatemaltecas, el 31 de enero de 1980, fue Venezuela el Estado que asumió la protección de intereses de España en el país centroamericano con la integración de un diplomático español ${ }^{13}$.

La aplicación típica del art. 46 del Convenio de 1961 se advera en el Tratado de Buena Vecindad, Amistad y Cooperación entre el Reino de España, la República Francesa y el Principado de Andorra, de 1 y 3 de junio de $1993^{14}$. Otros ejemplos típicos de representación en situaciones normales son los de San Marino representado por Italia, Liechtenstein por Suiza, y Luxemburgo, representado por Países Bajos o Bélgica ${ }^{15}$. En el derecho consular la disposición equivalente es la del art. 27 del Convenio de 1963.

En determinadas circunstancias, a la representación por el Estado representante acompaña la desaparición de la misión diplomática del Estado representado; en otros casos, la misión diplomática del Estado representante dispondrá en su seno de una sección de intereses constituida por su propio

12 Véase el completo estudio de estas instituciones realizado, en la doctrina española, por VILARIÑO op. cit., nota 9, p. 190. El profesor VILARIÑO cita el ejemplo de la representación por España de Egipto en los Estados Unidos de América, y de estos en Egipto, después de la ruptura bilateral de relaciones diplomáticas en 1967, p. 192. En la doctrina anglosajona, véase el comentario a los art.s citados de Eileen DENZA, Diplomatic Law, Commentary on the Vienna Convention on Diplomatic Relations, Oxford University Press, Oxford, 2008.

13 Véase la cita de este caso realizada por José Antonio DE YTURRIAGA BARBERÁN, Los órganos del Estado para las relaciones exteriores. Compendio de Derecho diplomático y consular, Escuela Diplomática, Ministerio de Asuntos Exteriores y de Cooperación, Madrid, 2016, p. 155.

14 En efecto, el art. 6 prevé que o bien España o bien Francia se encarguen de la protección de los intereses y la representación diplomática de Andorra ante terceros Estados, conferencias u organizaciones internacionales, si el Principado decide no encargarse por sí mismo, de conformidad con la Convención de 1961. Las modalidades de dicha representación y protección se determinarán en acuerdos específicos. Y el art. 7 contempla la posibilidad de la representación consular, de modo que los nacionales andorranos puedan acudir, en caso de necesidad, bien a una oficina consular de España, bien a una oficina consular de Francia, si ambas coexisten (BOE núm. 155, de 30 de junio de 1993, p. 19876).

15 SALMON, op. cit. nota 8, p. 117. 
personal y por otro tipo de personal, incluido el diplomático, perteneciente a la antigua misión del Estado representado. Este personal antiguo se entenderá que forma parte de la misión diplomática del Estado representante.

En el punto IV se estudiarán los casos de la práctica de España y, en concreto, concluiremos que España no ha representado diplomáticamente a los Emiratos Árabes Unidos en la República Dominicana, según un memorando de entendimiento sobre representación diplomática y su protocolo de aplicación, firmados recientemente ${ }^{16}$. No constituye propiamente representación internacional porque, en esta, el Estado representante (España) actúa por medio de sus propios órganos, lo que no sucede si los Emiratos Árabes Unidos confieren su representación en la República Dominicana a un agente diplomático propio.

Un caso muy singular ${ }^{17}$ por la naturaleza y funciones de una de las partes es el de la protección por España de los intereses del Alto Representante en Bosnia y Herzegovina, su oficina y su personal, instrumentada en un tratado bilateral ${ }^{18}$.

16 MOU de 29 de mayo de 2009. Fuente: Ministerio de Asuntos Exteriores y de Cooperación (MAEC).

17 La singularidad de este tipo de protección de intereses se observa particularmente en las disposiciones del Acuerdo bilateral, que contemplan un plazo de 25 años de ejercicio de esa protección, tras el cierre de la Oficina del Alto Representante (art. 13); también, el hecho de que los archivos de la oficina se custodien en la Embajada de España en Bosnia y Herzegovina, sin ser de la propiedad de España (art. 6); y que una supuesta ruptura de relaciones diplomáticas de España con el resto de Estados implicados en este tema supondrá la cesión de sus funciones de protección de intereses a alguno de los miembros del Consejo de Administración del Consejo de Aplicación del Acuerdo de Paz (art. 9). En este mismo sentido, el Dictamen del Consejo de Estado núm. 376/2014, de 29 de mayo de 2014, sobre la tramitación del tratado, resuelve la necesidad de la previa autorización de las Cortes Generales al contener el Acuerdo disposiciones sobre el reconocimiento de privilegios e inmunidades «a un organismo internacional», caracterizándolo más concretamente como «una institución internacional ad hoc». Además, el Consejo de Estado subsume el Acuerdo entre los supuestos del art. 94.1.e) de la Constitución al «comportar el reconocimiento de un estatuto especial que conlleva ciertas excepciones frente al general reconocido por normas con rango de ley, como resulta de la inmunidad de jurisdicción o la inviolabilidad personal y domiciliaria».

18 Acuerdo entre el Reino de España y el Alto Representante en Bosnia y Herzegovina sobre la Protección de los Intereses del Alto Representante en Bosnia y Herzegovina, su Oficina y su personal, de 24 de junio de 2014 (BOE núm. 36, de 11 de febrero de 2015, p. 11568). 


\section{FUNCIONES CONSULARES EN TERCEROS ESTADOS Y POR CUENTA DE UN TERCER ESTADO}

En paralelo a la acreditación diplomática múltiple regulada en el art. 5.1 del Convenio de 1961, a la que haremos referencia posteriormente, el art. 7 del Convenio de 1963 recoge la posibilidad de que el Estado que envía una oficina consular, tras la notificación a los Estados interesados y salvo oposición expresa de los mismos, pueda encargar a esa oficina el ejercicio de funciones consulares en terceros Estados.

Otra institución bien conocida en el Derecho de la UE, dentro del estatuto de la ciudadanía de la Unión ${ }^{19}$, es la del art. 8 del Convenio de 1963, según la cual la oficina consular del Estado que envía podrá ejercer en el Estado receptor funciones consulares por cuenta de un tercer Estado, a favor de los nacionales de éste. Las funciones consulares reguladas en el art. 5 del Convenio de 1963 se ejercerán en casos de inexistencia de relaciones consulares, de ausencia de oficinas consulares en una determinada circunscripción, y en supuestos de incapacidad de protección aun existiendo embajada, consulado o cónsul honorario ${ }^{20}$. Atendiendo a la práctica europea, que es seguramente la más desarrollada en esta materia, los requisitos de la protección y asistencia consular son de dos tipos: primero, un vínculo jurídico entre los dos Estados concernidos por la protección, ya sea una norma institucional (una directiva,

19 Con base jurídica en el art. 20. 2.c) del TFUE, completado por las previsiones del art. 23 del TFUE, y según lo previsto en el art. 46 de la Carta de Derechos Fundamentales de la UE. Véase el comentario al art. 46 de la Carta de Derechos Fundamentales de la UE realizado por Araceli MANGAS MARTÍN, en Carta de los Derechos Fundamentales de la Unión Europea. Comentario art. por art., Fundación BBVA, Bilbao, 2008, pp. 731-736.

20 Véase, Eduardo VILARIÑO PINTOS, «Representación exterior y cooperación diplomática y consular en el Tratado de la Unión Europea», RIE, v. 22, núm. 2, 1995 , pp. 417-443. Más recientemente, Elena CRESPO NAVARRO, Nuevas formas de protección del individuo en Derecho internacional, Tirant Lo Blanch, Valencia, 2005; Paz ANDRÉS SÁENZ DE SANTAMARÍA, «La protección diplomática y consular de los ciudadanos de la Unión en el exterior", Revista de Derecho de la Unión Europea, núm. 11, 2006, pp. 11-25; Adela REY ANEIROS, «Hacia el reforzamiento de la dimensión exterior de la ciudadanía europea», RDCE, núm. 26, 2007, pp. 9-43, y Mónica GUZMÁN ZAPATER, «El Servicio Europeo de Acción Exterior y la protección consular de los ciudadanos de la Unión Europea», en Francisco ALDECOA LUZÁRRAGA, Carlos R. FERNÁNDEZ LIESA, Montserrat ABAD CASTELOS (dirs.), Gobernanza y reforma internacional tras la crisis financiera y económica: el papel de la Unión Europea, Marcial Pons, Madrid, 2014, pp. 149-164. 
una decisión, o un reglamento de la UE) o un acuerdo bilateral, formal o informal; segundo, la previa notificación adecuada al Estado receptor y que este no se oponga. Además, los arts. 20.2.c y 23 del Tratado de Funcionamiento de la UE (TFUE) imponen dos requisitos o limitaciones particulares: que la protección del Estado que envía al ciudadano no representado sea en las mismas condiciones que existen para los nacionales de dicho Estado, y que los Estados miembros establezcan las normas necesarias y entablen negociaciones internacionales para garantizar dicha protección. Sabido es, por lo demás, que la protección a la que se refieren estas disposiciones y el derecho derivado posterior, que utiliza indistintamente los términos "protección y asistencia consular ${ }^{21}$, no consiste en una protección diplomática y consular en el sentido técnico del derecho internacional ${ }^{22}$. Realmente, el alcance de esta protección vendrá determinado en cada una de las acciones normativas y administrativas de la UE y de sus Estados miembros.

En el ámbito de la UE, ampliado en un caso al espacio Schengen, se han regulado dos grandes tipos de cooperación consular que no pueden confundirse ${ }^{23}$. En primer lugar, entran en juego los «acuerdos prácticos» para la

21 Como bien apunta el diplomático Xavier MARTÍ MARTÍ en «La política española de protección y asistencia consulares a los ciudadanos españoles detenidos en el extranjero", Revista Española de Derecho Internacional, vol. 65, 2013, pp.. 43-72, p. 45, en el derecho español también se confunden las instituciones «protección consular» y «asistencia consular», como sucede en la Orden AEX/10592002, de 25 de abril, de bases reguladoras de las ayudas de protección y asistencia consulares en el extranjero (BOE núm. 115, de 14 de mayo de 2002, p. 17475). Otro diplomático discrepa sobre esa distinción y entiende que la protección subsume a la asistencia, de manera que «el Estado que envía debe proteger a sus nacionales cuando se encuentren en el extranjero y proporcionarles asistencia y ayuda, sin necesidad de que se tenga que producir un comportamiento inadecuado del Estado receptor contrario a derecho» (véase DE YTURRIAGA, op.cit. nota 13, p. 243).

22 Así lo reconocen varios autores que han estudiado este tema, como los citados en la nota 17 y los siguientes: Carlos JIMÉNEZ PIERNAS, «La protección diplomática y consular de los ciudadanos de la Unión Europea», Revista de Instituciones Europeas, vol. 20, 1993, pp. 9-49; María Dolores BLÁZQUEZ PEINADO, La ciudadanía de la Unión, Tirant Lo Blanch, Valencia, 1998.

23 Sobre la expedición de visados y la protección consular como funciones para las delegaciones de la UE, véase Carmela PÉREZ BERNÁRDEZ, «Hacia el complejo establecimiento de un SEAE: Las futuras Embajadas de la Unión Europea», en Francisco ALDECOA LUZÁRRAGA, José Manuel SOBRINO HEREDIA, Luis Norberto GONZÁLEZ ALONSO, Antonio PASTOR PALOMAR, Joaquim FORNER DELAYGUA, Mónica HERRANZ BALLESTEROS, Carmela PÉREZ BERNÁRDEZ 
prestación de la protección consular a ciudadanos de la UE no representados en terceros Estados, que serán facultativamente convenidos entre Estados miembros. La posible celebración de tales acuerdos interestatales fue establecida en el art. 4 de la Decisión 95/553 de los representantes de los gobiernos de los Estados miembros reunidos en el seno del Consejo, de 19 de diciembre de $1995^{24}$, y, posteriormente, en el art. 7 de la Directiva (UE) 2015/637 del Consejo, de 20 de abril de 2015.

El segundo tipo relevante de cooperación consular europea se materializa en los «acuerdos de representación» relativos a la política de visados de la UE, previstos en el art. 8 del Código Comunitario sobre Visados de 2009. Este Código permite utilizar distintos tipos de estructura organizativa de los Estados miembros en un tercer Estado para facilitar los procedimientos de expedición de visados ${ }^{25}$. Por el momento, las delegaciones de la UE no han intervenido en estas funciones, más allá de realizar un seguimiento general de

(coords.), Los Tratados de Roma en su cincuenta aniversario. Perspectivas desde la AEPDIRI, Marcial Pons, Madrid, 2008, pp. 1339-1366, p. 1358.

24 Que la Comisión Europea califica como «decisiones intergubernamentales sui generis», en la Comunicación de la Comisión al Consejo, al Parlamento Europeo, al Comité Económico y Social Europeo y al Comité de las Regiones: protección consular para los ciudadanos de la UE en terceros países: situación actual y perspectiva futura, COM (2011) 149 final, 23.3.2011, p. 5. Para la profesora MANGAS MARTÍN, $o p$. cit., nota 20, p. 736, estas decisiones son acuerdos internacionales jurídicos en forma simplificada.

De conformidad con el Reglamento (CE) núm. 810/2009 del Parlamento Europeo y del Consejo, de 13 de julio de 2009, por el que se establece un Código Comunitario sobre Visados (DO L 243, de 15 de septiembre de 2009, p. 1). Su art. 8.1 permite a un Estado miembro aceptar representar a otro a efectos de examinar las solicitudes y expedir los visados en nombre de ese Estado miembro. Y un Estado miembro también podrá representar a otro únicamente para la recepción de solicitudes y el registro de identificadores biométricos. Con estos fines pueden celebrarse acuerdos de representación, con las características especificadas en el art. 8.4. España ha celebrado con Estonia el Canje de Notas constitutivo de Acuerdo, de 25 de marzo y 14 de mayo de 2010, por el que se enmienda el Acuerdo entre el Reino de España y la República de Estonia para la representación en la expedición de visados Schengen, de 11 de febrero de 2009 (BOE 153, de 24 de junio de 2010, p. 55022). Además, España ha celebrado otros acuerdos de representación en materia de visados con los Estados Schengen que no se han considerado tratados y no han sido publicados oficialmente, aunque sí consta públicamente su comunicación a la Comisión Europea, según información disponible en: http://www.exteriores.gob.es/Portal/es/ServiciosAlCiudadano/InformacionParaExtranjeros/Paginas/VisadosUniformeSchengen.aspx. 
las representaciones en sus respectivas demarcaciones, cuestión que se volverá a tratar en el punto III.

Al margen de la UE y de la Comunidad Iberoamericana - por la intervención de Francia y por el objeto del instrumento-, el Tratado de Buena Vecindad, Amistad y Cooperación entre el Reino de España, la República Francesa y el Principado de Andorra, de 1 y 3 de junio de 1993, prevé la representación consular de los nacionales andorranos en una oficina consular, bien de España o bien de Francia, en la medida en que ambas coexistan ${ }^{26}$.

\section{EL INTERCAMBIO Y LA COLOCACIÓN DE PERSONAL DIPLOMÁTICO Y CONSULAR}

En los últimos años se ha potenciado la práctica interestatal relativa al intercambio y a la colocación de personal diplomático en los servicios centrales del MAEC (España y Alemania intercambian funcionarios diplomáticos en los servicios centrales de sus respectivos ministerios) ${ }^{27}$. Lo mismo sucede con la colocación de diplomáticos en delegaciones de una organización internacional ${ }^{28}$ (España ha colocado a un encargado de negocios ad interim, dependiente de la Embajada de España en Tailandia, en los locales de la delegación de la UE en Myanmar), así como en misiones diplomáticas, consulados y oficinas diplomáticas sectoriales en terceros Estados (España y Portugal permiten el uso de sus respectivas instalaciones e infraestructura de sus embajadas y consulados en terceros Estados). En la arena diplomática esta práctica se conoce con el término colocación, en inglés co-location, y en francés colocalisations. Por tanto, afecta a lo que denominaremos «acuerdos de colocación».

La colocación de uno o varios agentes diplomáticos de un Estado en una embajada del Estado acreditante o en una delegación de una organización internacional, ante el Estado receptor, puede ser para el primer Estado una forma alternativa y complementaria a la acreditación múltiple, prevista en el art. 5.1 del Convenio de 1961. Así, la Embajada de España en Tailandia también

26 BOE núm. 155, de 30 de junio de 1993, p. 19876.

27 Con base en la Declaración conjunta del Ministro de Asuntos Exteriores y de Cooperación del Reino de España y el Ministro de Asuntos Exteriores de la República Federal de Alemania relativa al intercambio de funcionarios diplomáticos, de 10 de noviembre de 2006 (Fuente: MAEC).

28 A propósito de la evolución en la configuración de las delegaciones de la UE, véase el trabajo de PÉREZ BERNÁRDEZ, op. cit., nota 24, p. 1345. 
está acreditada en Camboya y Laos pero, como se ha visto, se ha colocado a un encargado de negocios ad interim en la delegación de la UE en Myanmar.

En la acreditación múltiple el Estado acreditante (por ejemplo, España) notifica a varios Estados o territorios receptores (Nueva Zelanda, Islas Cook, Islas Fiji, República de Kiribati, Estado independiente de Samoa, Reino de Tonga) que un jefe de misión (el embajador de España en Nueva Zelanda ${ }^{29}$ está acreditado — simultánea y nominalmente- ante esos Estados, siendo sólo en uno de ellos residente. Como se ha visto, la acreditación múltiple también permite el establecimiento de una misión diplomática reducida, en régimen de colocación en locales de la misión de otro Estado o en locales propios, y dirigida por un encargado de negocios ad interim en cada uno de los Estados en que el jefe de misión no tenga su sede permanente. La acreditación múltiple de los Estados es igualmente frecuente ante las organizaciones internacionales, por ejemplo, ante la $\mathrm{UE}^{30}$ que, a su vez, puede tener delegaciones diplomáticas ante varios Estados de una región, como la Delegación para el Pacífico que comprende a quince Estados y territorios ${ }^{31}$.

En conclusión, la compartición de embajadas, delegaciones y consulados se realiza por España y otros Estados y Organizaciones internacionales mediante formas de cooperación variadas e instrumentadas en acuerdos de naturaleza diversa. Algunas de estas formas se han potenciado en los últimos años por las causas que, a continuación, serán estudiadas.

29 Véase el Real Decreto 799/2015, de 4 de septiembre, por el que se designa embajador de España en Nueva Zelanda a don Manuel Pradas Romaní (BOE núm. 213, de 5 de septiembre de 2015, p. 78639). Y en relación con este, el Real Decreto 1158/2015, de 18 de diciembre, por el que se designa Embajador de España en el Estado independiente de Samoa a don Manuel Pradas Romaní (BOE núm. 303, de 19 de diciembre de 2015, p. 119963), así como el Real Decreto 1159/2015, de 18 de diciembre, por el que se designa Embajador de España en las Islas Cook a don Manuel Pradas Romaní (BOE núm. 303, de 19 de diciembre de 2015, p. 119964).

30 Puede comprobarse en la lista de las misiones diplomáticas acreditadas ante la UE y EURATOM del servicio de protocolo de la Comisión Europea, disponible en: http:// ec.europa.eu/dgs/secretariat_general/corps/index.cfm?go=search.search\&missions $=1$ (consultado el 8.4.2016). Una buena parte de los Estados acreditan también ante otros Estados, como Bélgica, Luxemburgo y Países Bajos, a su embajador ante la UE y EURATOM.

31 Información del Servicio Europeo de Acción Exterior, disponible en: http://eeas.europa.eu/delegations/fiji/index_en.htm (consultado el 8.4.2016). 


\section{LAS CAUSAS DEL NACIMIENTO Y DESARROLLO DE ESTAS NUEVAS FORMAS DE DIPLOMACIA}

\section{LAS SINERGIAS DIPLOMÁTICAS Y ECONÓMICAS CON SOCIOS PRIVILEGIADOS}

La consecución de sinergias diplomáticas, consulares y económicas entre los Estados miembros, y entre estos y las delegaciones de la UE, se fundamentan en los instrumentos jurídicos vigentes de la UE; y dentro de ellos, en los elementos institucionales de la acción exterior, en las políticas internas de la Unión vinculadas a las funciones consulares interestatales y en el estatuto conferido por la ciudadanía de la Unión. Este es un ejemplo más de la fértil relación entre el derecho de la UE y el derecho internacional, si bien, la compartición de embajadas y consulados no es un fenómeno exclusivo de la UE, pues se presenta igualmente en la Comunidad Iberoamericana de Naciones - como se verá posteriormente-, en el marco de la Alianza del Pacífico (Colombia, Chile, México y Perú) ${ }^{32}$, entre los países nórdicos de Europa ${ }^{33}$, y en el ámbito de alguno de los cincuenta y tres Estados pertenecientes a la Commonwealth (Reino Unido, Australia, Canadá y Nueva Zelanda, entre otros) $)^{34}$.

El establecimiento del Servicio Europeo de Acción Exterior (SEAE), según lo previsto en el art. 27.3 del Tratado de la UE (TUE) y en la Decisión del Consejo de 26 de julio de $2010^{35}$, ha fermentado una cierta reestructuración

32 Los cuatro Estados comparten sedes diplomáticas en Ghana; Colombia y Perú en Vietnam; Chile y Colombia en Marruecos, Argelia, Azerbaiyán y la misión ante la OCDE; Colombia y México en Singapur. Información disponible en el sitio web de la Cancillería del Gobierno de Colombia: www.cancilleria.gov.co

33 Como se constata en el documento del PARLAMENTO EUROPEO, The role of the European external action service in consular protection and services for EU citizens, 2013, p. 13.

34 FOREIGN AND COMMONWEALTH OFFICE, Anuual Report and Accounts: 2014-2015, FCO, 2015, p. 24. El Reino Unido ha realizado veinticinco colocaciones con Australia, Canadá, Nueva Zelanda, Alemania y Francia. Sobre este fenómeno de la diplomacia de la austeridad, puede leerse el sugestivo art. de Alex OLIVER, "The irrelevant diplomat. Do we need embassies anymore», Foreign Affairs, 14 de marzo de 2016, disponible en: www.foreignaffairs.com.

35 Decisión del Consejo de 26 de julio de 2010 por la que se establece la organización y el funcionamiento del Servicio Europeo de Acción Exterior (DO L 201, de 3 de agosto de 2010, p. 30). El SEAE se puso en práctica el 1 de enero de 2011. Su creación ha supuesto la modificación del estatuto del personal de la UE y del 
de la diplomacia europea con el fin de aumentar su eficiencia, visibilidad, coordinación y coherencia ${ }^{36}$. Persiste la dualidad de representación exterior (UE-Estados miembros), en perjuicio de la representación única o de la unidad de acción ${ }^{37}$ pero, al menos, el art. 35 del TUE así como el art. 221.2 del Tratado de Funcionamiento de la UE (TFUE) contienen las bases jurídicas principales para las formas de cooperación institucional entre las misiones

reglamento financiero para incluir al nuevo organismo autónomo, por lo que son relevantes el Reglamento (UE, EURATOM) núm. 1080/2010, del Parlamento Europeo y del Consejo, de 24 de noviembre de 2010, por el que se modifica el Estatuto de los Funcionarios de las Comunidades Europeas y el régimen aplicable a los otros agentes de las Comunidades (DO L 311, de 26 de noviembre de 2010, p. 1) , y el Reglamento (UE, EURATOM) núm. 1081/2010, del Parlamento Europeo y del Consejo, de 24 de noviembre de 2010, que modifica el Reglamento (CE, EURATOM) núm. 1605/2002 por el que se aprueba el Reglamento financiero aplicable al presupuesto general de las Comunidades Europeas en relación con el Servicio Europeo de Acción Exterior (DO L 311, de 26 de noviembre de 2011, p. 9).

36 Sobre el tema, véase el trabajo de Dimitar DERMENDZHIEV, «The emergence of a network of 'European Embassies': increasing cooperation between EU delegations and member States diplomatic missions», EU Diplomacy Paper, College of Europe, Brugge, núm. 10, 2014, p. 15, quien habla de una diplomacia postmoderna.

37 Los hechos de las relaciones internacionales y la mejor doctrina, que interpreta aquellos, constatan incesantemente la necesidad de mejorar la unidad de acción exterior entre la UE y sus Estados miembros. Véase, al respecto, la opinión de Araceli MANGAS MARTÍN y Diego J. LIÑÁN NOGUERAS, Instituciones y Derecho de la Unión Europea, Tecnos, Madrid, 2014, p. 524. También, la obra colectiva coordinada por Francisco ALDECOA LUZÁRRAGA, La diplomacia común europea. El Servicio Europeo de Acción Exterior, Marcial Pons, Madrid, 2011; igualmente, Carmen MARTÍNEZ CAPDEVILA, «La adecuación del Servicio Europeo de Acción Exterior a los retos globales de la UE: unas reflexiones en clave crítica», Revista General de Derecho Europeo, núm. 24, 2011, pp. 1-18; Natividad FERNÁNDEZ SOLA, «The Stakes of the European External Action Service. What is needed in order to become a European Diplomatic Corps?», en José María BENEYTO (dir.), La Unión Europea como actor global. Las nuevas dimensiones de la política exterior europea, Biblioteca Nueva, Madrid, 2011, pp. 49-67. Para una descripción detallada y de primera mano del funcionamiento y de la organización del SEAE, véase el trabajo del embajador en misión especial para las relaciones con instituciones de la UE, Enrique GONZÁLEZ SÁNCHEZ, «El Sevicio Europeo de Acción Exterior: organización y funcionamiento», en José MARTÍN Y PÉREZ DE NANCLARES (dir.), España y la práctica del Derecho internacional. LXXV Aniversario de la Asesoría Jurídica Internacional del MAEC, Escuela Diplomática, Madrid, 2014, pp. 361-379. 
diplomáticas de los Estados miembros y las delegaciones de la UE ${ }^{38}$. La Alta Representante de la Unión para Asuntos Exteriores y Política de Seguridad se apoyará en el SEAE, que consta de una administración central y de las delegaciones de la Unión en terceros Estados y organizaciones internacionales. A su vez, de conformidad con la citada Decisión de 2010, las delegaciones de la UE «colaborarán estrechamente y compartirán información con los servicios diplomáticos de los Estados miembros» (art. 5.9) y "apoyarán a los Estados miembros, a petición de estos, en sus relaciones diplomáticas y en su función de prestación de protección consular a los ciudadanos de la Unión en países terceros, basándose en la neutralidad en lo que se refiere a recursos» (art. $5.10)^{39}$.

Para el Gobierno de España esta cooperación con el SEAE y con la Comunidad Iberoamericana forma parte de su Estrategia de Acción Exterior ${ }^{40}$. Como se desprende del Informe Anual de Aplicación de la Estrategia de Acción Exterior 2015, la planificación general del despliegue diplomático de los Estados miembros todavía no se realiza, más que en casos contados, según la estructura de las delegaciones de la UE en terceros Estados ${ }^{41}$.

Entre España y los otros Estados que conforman la Comunidad Iberoamericana también se han celebrado acuerdos de colocación de personal di-

38 También, el párrafo tercero del art. 32 del TUE, que dispone la cooperación de las misiones diplomáticas de los Estados miembros y las delegaciones de la Unión, así como la contribución a la formación y puesta en práctica de un enfoque común.

39 Un comentario al art. 5 y al resto de la Decisión 2010/427/UE, en Steven BLOCKMANS y Christophe HILLION (eds.), EEAS 2.0. A legal commentary on Council Decision 2010/427/EU establishing the organisation and functioning of the European External Action Service, CEPS, Brussels, 2013, p. 31. También, para el proceso de negociación de la Decisión de 2010, véase Juan SANTOS VARA, «El Servicio Europeo de Acción Exterior: un nuevo instrumento para mejorar la eficacia y coherencia de la acción exterior", Revista General de Derecho Europeo, núm. 24, 2011, pp. 1-32; y Mercedes GUINEA LLORENTE, «El Servicio Europeo de Acción Exterior: génesis de una Diplomacia Común Europea», Revista de Derecho Comunitario Europeo, núm. 37, 2010, pp. 761-800.

40 Esos acuerdos de colocación los firma la Alta Representante de la Unión junto con el ministro de Asuntos Exteriores del Estado miembro concernido. Las bases jurídicas puede encontrarse en los arts. 18, 24 y 27.3 del TUE, así como los arts. 1.3 y 5.6 de la Decisión de 2010. En el Derecho español, la base jurídica reside en el art. 49 de la LASE.

41 Así lo reconoce también el PARLAMENTO EUROPEO, op. cit., nota 36, p. 13. 
plomático y consular, lo que permite la extensión del marco de sus relaciones con terceros Estados y compartir experiencias ${ }^{42}$.

Como se ha estudiado anteriormente, otra fuente de cooperación institucional entre la UE y los Estados miembros reside en la protección consular, o sea, el ejercicio de funciones consulares por cuenta de otro Estado. La Directiva (UE) 2015/637, de 20 de abril de 2015, entiende que esta protección a los ciudadanos de la UE no representados "es una expresión de la solidaridad europea» (considerando $3^{\circ}$ ) y, por ende, de los valores en los que se funda la Unión, que debe «aumentar la seguridad jurídica» (considerando $4^{\circ}$ ). La Directiva es rica en problemas interesantes para el derecho internacional, pero en este trabajo el foco se orienta hacia la cooperación institucional diplomática y consular. Por consiguiente, hágase notar que la protección consular a los ciudadanos no representados en un tercer Estado se presta realmente por las embajadas o consulados de los Estados miembros (art. 2.1.), y la Directiva establece las medidas de coordinación y cooperación necesarias al efecto. Se prevé un papel subordinado al de las misiones estatales para las delegaciones de la UE (art. 1.1). En el considerando $6^{\circ}$ se especifica que esta cooperación no afecta a las relaciones consulares entre los Estados miembros y terceros Estados, de modo que se aplica el Convenio de 1963, cuyo art. 8 requiere la previa notificación al Estado receptor y que este no se oponga. La carencia de representación consiste en que el Estado miembro, del que es nacional el ciudadano, no disponga de embajada o de consulado establecidos con carácter permanente o que no se pueda prestar una protección eficaz aun existiendo embajada, consulado o cónsul honorario en el tercer Estado (art. 6). La ausencia de representación debe interpretarse de manera que se garantice el derecho del ciudadano de manera no discriminatoria (considerando $8^{\circ}$ ).

El ciudadano europeo necesitado puede elegir la embajada o el consulado de cualquier Estado miembro (art. 7.1). Y el art. 7.2 permite los acuerdos de representación permanente entre los Estados miembros. En el art. 7.3 de la Directiva se prevé que, cuando los Estados miembros lo estimen necesario, se podrán alcanzar «acuerdos prácticos» sobre el reparto de responsabilidades para la prestación de protección consular. La Decisión de 1995 ya preveía estos acuerdos prácticos por lo que cabe presumir que España los ha suscrito con otros Estados miembros. Sin embargo, no se conocen públicamente. Puede interpretarse que los acuerdos se alcanzan en las reuniones de cooperación consular, cuyas actas deberían anotarlos; de hecho, el art. 12 prevé el intercambio periódico de información en las reuniones de cooperación local.

42 A este tipo de diplomáticos se les conoce en inglés como «laptop diplomats» (véase PARLAMENTO EUROPEO, op.cit. nota 36, p. 13). 
A modo de mejora en el régimen, el art. 7.2 de la Directiva prevé que los Estados informen a la Comisión y al SEAE de este tipo de acuerdos, que recibirán publicidad "para garantizar la transparencia para los ciudadanos no representados».

Con todo lo anterior, no creo que pueda afirmarse que se pretenda la creación de un modelo centralizado en la UE de protección y asistencia consular ${ }^{43}$.

Las delegaciones de la UE poseen un papel mucho menor en relación con otro tipo de función consular, la representación de los Estados para la expedición de visados Schengen. En efecto, el art. 8.8 del Código Comunitario sobre Visados es la única disposición que prevé un papel concreto para esas delegaciones, pues el Estado que representa debe informar localmente a los Estados miembros y a esas delegaciones de la UE sobre la representación que asuma o que, en su caso, termine. El motivo prioritario de esta cooperación residiría en mejorar los sistemas de trabajo y, por ende, el sistema de visados Schengen, junto a la reducción de costes. Dado que se tiene constancia de los acuerdos de representación celebrados por España a través de la Dirección General de Españoles en el Exterior y de Asuntos Consulares y Migratorios, su análisis se realizará en los puntos IV y V de este trabajo ${ }^{44}$.

En conclusión, las sinergias diplomáticas y consulares con socios privilegiados, así como la economía de los medios, se consiguen sobre la base de un marco jurídico fundamental.

\section{NUEVAS LEYES DE ESPAÑA (LASE Y LTOAI). LOS CASOS REGULADOS}

La entrada en vigor de la LASE, el 27 de marzo de 2014, ha formalizado con sus arts. 42, 49, 50 y 52 esta práctica diplomática y consular que, existiendo con anterioridad a la aprobación de la Ley, es probable que se vea impulsada y ordenada con estos nuevos mimbres a pesar de las sombras que proyectan. Esas previsiones del título II, capítulo II, de la LASE, responden a ese principio común de cooperación en dos ámbitos geográficos diferentes, la UE y la Comunidad Iberoamericana de Naciones. La cooperación diplomática y consular en el marco de la UE se regula en los arts. 42, 49 y 50 de la LASE

43 Sobre esta cuestión de la centralización de funciones, véase el trabajo de GUZMÁN, op. cit., nota 21, p. 162.

44 Puede consultarse la lista de acuerdos de representación publicada por el MAEC en su sitio web: http://www.exteriores.gob.es/Portal/es/ServiciosAlCiudadano/InformacionParaExtranjeros/Documents/Lista\%20de\%20Representaciones $\% 20$ para $\% 20$ la\%20expedición\%20del\%20visado\%20uniforme.pdf 
y en la esfera de la Comunidad Iberoamericana, en el art. 52. Las formas de cooperación previstas en uno y otro ámbito geográfico no son idénticas, como se desprende del contenido material de los preceptos, pero sí coinciden las normas de competencia y procedimiento sobre los acuerdos que se formalicen a este respecto. Las diferencias se deben a la especificidad del derecho de la UE, no obstante lo cual, en este trabajo se plantea la necesidad de una interpretación conjunta de unas y otras previsiones.

En relación con la UE, la letra $f$ del art. 42 incorpora una de las funciones de las misiones diplomáticas permanentes del Servicio Exterior del Estado, y dispone la cooperación «con las instancias de representación exterior de la UE en la identificación, defensa y promoción de los intereses y objetivos de su acción exterior». Este enunciado sirve para extender la cooperación de las misiones diplomáticas permanentes de España con el SEAE y las delegaciones de la UE, dentro y más allá de los acuerdos de colocación, los acuerdos prácticos de protección y asistencia consular, y los acuerdos de representación en materia de visados Schengen, que son los ámbitos hasta ahora desarrollados. La disposición fue propuesta como enmienda por el Grupo Mixto ${ }^{45}$ y por el Grupo Parlamentario Popular durante la tramitación del proyecto de ley en el Senado, prosperando exitosamente bajo la justificación de que su contenido «implica una mayor colaboración en las delegaciones de la UE en el exterior y con las instituciones europeas, siguiendo el espíritu de la política exterior española y de los Tratados de la UE» ${ }^{46}$.

A esa disposición tan general y tan en línea con la letra del derecho de la UE, se añade otra de índole procedimental. El art. 49 de la LASE prevé varias formas de cooperación diplomática de España «con los órganos competentes de la UE o de sus Estados miembros». De una lectura unitaria de los apartados primero y segundo del art. 49, se infiere que el instrumento previsto para esa cooperación diplomática es un «acuerdo» celebrado, de un lado, «con las instituciones de la UE» o con «las instituciones competentes de los Estados miembros» y, de otro lado, por el Gobierno de España, a iniciativa del MAEC y a propuesta del Ministerio de Hacienda y Administraciones Públicas, previo informe del Consejo Ejecutivo de Política Exterior.

Ello remite necesariamente a la LTOAI, que contiene las normas principales sobre la calificación, tramitación y celebración de acuerdos internacionales por España, con independencia de su denominación. En esta materia las dos leyes españolas resultan perfectamente compatibles; sin embargo, no ha sido pacífico entre los órganos consultivos del Estado (concretamente, entre la

45 Enmienda núm. 26, BOCG, Senado, núm. 293, de 3 de enero de 2014, pp. 202-203.

46 Enmienda núm. 352, BOCG, Senado, núm. 293, de 3 de enero de 2014, pp. 27-28. 
Abogacía General del Estado y la Asesoría Jurídica Internacional del MAEC ${ }^{47}$ ) el uso de la LASE como base legal de algunos acuerdos que instrumentan este tipo de diplomacia.

En cuanto a las formas de diplomacia que contiene el art. 49 cabe afirmar, de entrada, que la redacción de sus disposiciones no es clara, por lo que debe realizarse una labor interpretativa y, por ende, acudir al proceso de elaboración de la LASE ${ }^{48}$. Los tres primeros supuestos del apartado primero (a, b y c) comportan la creación de una nueva institución. Su redacción plantea dudas sobre las formas de diplomacia que se contemplan.

La creación de «misiones diplomáticas conjuntas» se prevé sólo con otros miembros de la UE en terceros Estados, lo que excluye la conjunción de una misión de España y de una delegación de la UE. Otra cosa es la posible «incorporación de funcionarios españoles a delegaciones de la UE en los Estados en que España no tenga misión diplomática permanente, a fin de que desempeñen determinadas funciones del Servicio Exterior español» (art. 49.1.d), que es un tipo de colocación; también es distinto «que funcionarios del Servicio Exterior español compartan servicios comunes con las delegaciones de la UE o con las misiones diplomáticas de otros Estados de la UE» (art. 49.1.e), que es otro tipo de colocación. No se contempla el intercambio de diplomáticos en los servicios centrales de los MAE. Por consiguiente, en su literalidad, el art. 49.1.a., que está redactado en plural, comprendería casos de acreditación conjunta por un Estado principal y otro secundario de la misma persona como jefe de misión ante un tercer Estado, según regula el art. 6 del Convenio de 1961. Ahora bien, sorprende que se regule como primer supuesto de la disposición una práctica inusual de España y de los Estados de la UE; así que cabe

47 Dictamen de la Abogacía General del Estado ref. A. G Asuntos Exteriores y Cooperación 4/14 (R-384/2014), de 26 de mayo de 2014, sobre el Memorando de Entendimiento y Acuerdo Específico entre el Ministerio de Asuntos Exteriores y de Cooperación de España y el Ministerio de Asuntos Exteriores de Colombia para permitir el uso de instalaciones e infraestructuras de las embajadas y consulados de las partes signatarias en terceros Estados. Véase, también, la Memoria de la Abogacía General del Estado-Dirección del Servicio Jurídico del Estado (2014), Ministerio de Justicia, 2015, p. 193, en la que se afirma que «durante el año 2014, como consecuencia de la entrada en vigor de la Ley 2/2014, de 25 de marzo, de la Acción y del Servicio Exterior del Estado, el MAEC ha impulsado la celebración de convenios con otros países y con la UE a fin de posibilitar el uso conjunto de instalaciones y la incorporación de funcionarios de la Carrera Diplomática a las respectivas Misiones Diplomáticas o Delegaciones de la UE. Estos acuerdos han sido objeto de especial consideración por esta Unidad». La falta de claridad de la disposición también es destacada por FERNÁNDEZ SOLA, op. cit., nota 7 . 
concluir por ahora que la redacción no ha sido cuidadosa, como hubiera sido deseable, con el fin de poder delimitar cada caso. Además, en esa disposición no encaja la representación o protección de intereses de los arts. 45 y 46 del Convenio de 1961, porque esta presupone una única representación.

Tampoco se encuadran en el art. 49 de la LASE los tipos señalados de colocación. Y otros arts. de la LASE que repercuten en estas formas de cooperación diplomática y consular no contienen ninguna disposición sobre ellas; así, el art. 44 sobre el jefe de misión, el art. 45, relativo a la organización de la misión diplomática, el art. 47 a propósito de las oficinas consulares y el 48 sobre las clases de oficinas consulares y su organización. Esto demuestra falta de coherencia sistémica ${ }^{49}$. Por cierto, la acreditación múltiple se regula específicamente en el art. 42.1 de la LASE, al prever que una misión represente a España ante varios Estados y con residencia en uno de ellos.

$\mathrm{Ni}$ el dictamen del Consejo de Estado al anteproyecto de ley ${ }^{50}$, ni la tramitación parlamentaria del proyecto de ley, arrojan luz para sostener otro tipo de interpretación sobre este punto concreto, pues no existen debates ni enmiendas relevantes ${ }^{51}$. Sin embargo, la enmienda — no aprobada ni reflejada de alguna manera en la LASE - del grupo Izquierda Plural tiene aspectos

49 El Dictamen del Consejo de Estado núm. 394/2013, de 31 de mayo de 2013, sobre el anteproyecto de ley, señaló las «carencias y desequilibrios» de la sistemática del conjunto del texto, p. 18.

50 Dictamen núm. 394/2013, de 31 de mayo de 2013, pp. 6, 14 y 18, en el que no se hace eco de los problemas jurídicos de fondo que plantean estas formas de cooperación diplomática y consular.

51 El art. 49 de la LASE (art. 48 del Proyecto de Ley) sólo produjo en el Congreso de los Diputados la enmienda núm. 176 del Grupo Parlamentario de Unión Progreso y Democracia, de carácter técnico, pues sirvió para cambiar el verbo «se inspira» por «se fundamenta» en el apartado 1.b. relativo a la creación de oficinas culturales conjuntas en terceros Estados, para difundir los principios y valores en que se fundamente la Unión; y la sustitución de «autoridades comunitarias» por «instituciones de la Unión Europea», en el último párrafo del apartado 2, relativo a los acuerdos de formalización de esta práctica (BOCG, Congreso de los Diputados, Serie A, núm. 51-2, de 31 de octubre de 2013, pp. 133-134). Hubo varias enmiendas a la totalidad de devolución: enmienda núm. 2, 4 y 5 del Grupo Parlamentario Mixto, enmienda núm. 3 del Grupo Parlamentario Vasco, enmienda núm. 6 del Grupo Parlamentario Socialista, en la que sólo se refiere a la insatisfactoria regulación de las disposiciones relevantes. En el Senado, tan sólo se presentó por el Grupo Parlamentario Popular la enmienda núm. 356 de modificación de redacción del art. 49 para sustituir oportunamente el término "países» por el de «Estados» (BOCG, Senado, núm. 293, de 3 de enero de 2014, p. 205). 
interesantes porque presenta un texto alternativo con incidencia en las disposiciones que nos ocupan ${ }^{52}$. En efecto, frente al silencio de la vigente LASE, se propone en el art. 22 la regulación de una sección de intereses, de los Estados cuya representación en el Estado receptor haya sido encomendada a España, integrada en las misiones diplomáticas permanentes de España ${ }^{53}$. También, en el art. 23 se presenta una regulación concreta de las misiones diplomáticas conjuntas con los Estados miembros de la UE en terceros Estados, e, igualmente, se prevé la colocación con la mención a la compartición de «servicios comunes con las misiones diplomáticas de los otros Estados miembros». Esta estructura mejora la interpretación de las normas.

Continuando con el comentario de la LASE, resulta más nítida la regulación de la creación de «oficinas culturales y sectoriales conjuntas» en terceros Estados, pues se estipula que estarán incardinadas en una delegación de la UE o en una misión diplomática española o en la de un Estado miembro. También, se requerirá la celebración de un acuerdo adoptado siempre por los mismos órganos competentes antes referidos, que concrete las condiciones de funcionamiento. En la fecha de realización del trabajo no se había producido ningún acuerdo sobre este supuesto.

$\mathrm{El}$ art. 50 de la LASE prevé la "creación de oficinas consulares conjuntas con Estados miembros de la UE en terceros Estados». Sus disposiciones padecen problemas de insuficiencia y deficiencia similares a los comentados anteriormente para las misiones diplomáticas. No se contempla el ejercicio de funciones consulares múltiples por una misma oficina consular en terceros Estados, según dispone el art. 7 del Convenio de 1963. Obvio es que cabe esa posibilidad en España al formar parte el tratado del derecho interno, según el art. 96.1 de la Constitución y el art. 23.3 de la LTOAI. Tampoco se considera la creación de una oficina consular con una delegación de la UE, sino con los Estados miembros. Por otro lado, no parece que la creación de oficinas conjuntas signifique el nombramiento por dos o más Estados miembros de un único cónsul actuante ante un mismo Estado receptor, caso que no está regulado en el Convenio de 1963. Tampoco comprende la colocación

52 El grupo parlamentario de IU, ICV-EUIA, CHA, La Izquierda Plural, presentó la enmienda núm. 1 a la totalidad con texto alternativo (BOCG, Congreso de los Diputados, núm. 51-2, de 31 de octubre de 2013, pp. 1-16). En coherencia con el texto de la enmienda a la totalidad con texto alternativo, se presentaron la enmienda núm. 93 (p. 77), para regular la creación de secciones de intereses, y la enmienda núm. 94 (p. 78), para regular las misiones diplomáticas conjuntas.

53 Además, acertadamente, el aparatado 2 de ese art. 22 propuesto en la enmienda de La Izquierda Plural, recoge que esas secciones de intereses «se regirán por las normas de derecho internacional y por los acuerdos concluidos por las partes interesadas». 
de funcionarios consulares de España en una oficina consular de otro Estado miembro, pues esta forma de cooperación queda prevista en el último inciso del apartado primero de este art. 50 de la LASE. No encajan, igualmente, los «acuerdos prácticos» de protección consular como derecho de la ciudadanía de la UE porque estos no comportan una representación conjunta, sino la de un Estado miembro por cuenta de otro; sin embargo, esos «acuerdos prácticos» crean un tipo de servicios comunes. Los «acuerdos de representación» en materia de visados Schengen tampoco conllevan la creación de una oficina consular conjunta sino, más bien, la compartición de otro tipo de servicios comunes, como se analizó en el punto correspondiente de este trabajo ${ }^{54}$. En suma, la redacción del art. 50 no se corresponde con la práctica que España ha generado, hasta el momento, con otros Estados miembros de la UE, salvo en la compartición de servicios comunes con las oficinas consulares de otros Estados miembros, que no queda restringida a la cooperación en materia de visados Schengen ${ }^{55}$.

Por lo que se refiere a la Comunidad Iberoamericana, el art. 52 de la LASE sustenta la cooperación diplomática y consular en «el diálogo, la

54 Véase el objeto del Canje de Notas constitutivo de Acuerdo por el que se enmienda el Acuerdo entre el Reino de España y la República de Estonia para la representación en la expedición de visados Schengen, de 11 de febrero de 2009, de 25 de marzo y 14 de mayo de 2010 (BOE núm. 153, de 24 de junio de 2010, p. 55.022; BOE núm. 243, de 7 de octubre de 2010, p. 84802).

55 En la tramitación parlamentaria, la enmienda núm. 1 de La Izquierda Plural (BOCG, Congreso de los Diputados, núm. 51-2, de 31 de octubre de 2013, p. 14) añade al art. 27, dedicado a las clases de oficinas consulares y organización, un apartado séptimo que lista las funciones consulares. Entre esas funciones consulares se explicita «a) la protección y asistencia consular a los ciudadanos españoles y a los de otros países a los que proceda otorgarlas de acuerdo con la ley, las normas de la UE y los convenios internacionales pertinentes; b) la concesión de visados y la aplicación de políticas migratorias, en colaboración con las oficinas consulares de los Estados miembros de la UE y, en especial, de los Estados miembros de los Acuerdos de Schengen». Como se ha visto en el trabajo, estas dos funciones responden a la práctica de España y su mención resulta acertada junto a otras funciones consulares. No obstante, puede criticarse que ello no se haya acompañado de una mejora en la redacción del art. 30 de la enmienda, relativo a las oficinas consulares conjuntas con países miembros de la UE, cuyo contenido es idéntico al del art. 50 de la LASE, con las deficiencias e insuficiencias que han sido apuntadas. Del mismo tenor son las enmiendas núm. 37 del Grupo Mixto del Senado (BOCG, Senado, núm. 293, de 3 de enero de 2014, pp. 33-34) y núm. 174 del Grupo Parlamentario Entesa pel Progrés de Catalunya (BOCG, Senado, núm. 293, de 3 de enero de 2014, pp. 106-107). 
solidaridad y la adopción de acciones concertadas». Aunque nada dice la disposición sobre la integración orgánica de las oficinas sectoriales conjuntas en terceros Estados, parece lógico que esta tendrá lugar en alguna de las misiones diplomáticas de los Estados que acuerden su apertura; interpretación fundada en lo dispuesto en el art. 49 para el marco de la UE. Efectivamente, los arts. 49 y 52 responden a principios comunes, como lo viene a poner de manifiesto su contenido similar y su ubicación en el capítulo III del título III de la LASE. Las diferencias de régimen jurídico en las formas de cooperación diplomática, por razón del ámbito geográfico, vendrán de la remisión explícita, en el caso del art. 49, al derecho de la UE. Cuando no exista dicha remisión, los supuestos serán asimilables, como demuestra el segundo párrafo del art. 52, que contempla el caso de la colocación o «incorporación recíproca de funcionarios de sus respectivos servicios exteriores en las misiones diplomáticas en terceros Estados». Cabe, por tanto, una interpretación conjunta de aquellos preceptos.

Evidentemente, de todo lo anterior resulta la necesidad de un análisis circunstanciado de cada caso de la práctica, tarea que se facilita a continuación mediante el establecimiento de unos criterios de clasificación.

\section{LOS CASOS DE LA PRÁCTICA DE ESPAÑA Y LA NATURALEZA DE LOS ACUERDOS}

\section{EN EL MARCO DE LA UNIÓN EUROPEA Y DEL ESPACIO SCHENGEN}

El análisis de la práctica muestra la presencia de cuatro grupos diferenciados de acuerdos de cooperación diplomática y consular de España con Estados miembros, con Estados Schengen no miembros de la UE y con el SEAE.

Sabemos que se desconocen públicamente los «acuerdos prácticos» de protección y asistencia consular que España pudiera haber celebrado con otros Estados miembros, en el contexto del estatuto de la ciudadanía de la Unión. Ello no excluye que estos acuerdos sean reales y que se hayan documentado en las actas de las reuniones de cooperación consular, que tampoco son públicas. Su naturaleza se determinará casuísticamente, dependiendo de los firmantes, del contenido y de las circunstancias de celebración. La LTOAI podría servir para ordenar esta práctica y reconducirlos hacia los tratados o, más probablemente, hacia los acuerdos internacionales administrativos aplicativos de una norma institucional de la UE. Por otro lado, las medidas de transposición nacionales podrían también configurarlos como acuerdos interadministrativos de derecho interno. Quedaría descartada, a priori, su naturaleza de acuerdos políticos, al regular cuestiones esencial- 
mente jurídicas y que requieren de la asunción de compromisos legales en ejecución de normas de la UE.

\section{A. Acuerdos de representación consular en materia de visados con Estados Schengen}

De esos cuatro grupos resultantes de la práctica de España destaca, por el número de casos, el de los acuerdos en materia de representación de visados Schengen, celebrados en virtud del art. 8 del Código de Visados ${ }^{56}$. Su existencia se conoce públicamente por los cuadros estadísticos que los Estados miembros pasan a la información de las instituciones de la UE ${ }^{57}$. España es representada en terceros Estados por once Estados miembros de la UE: Alemania, Bélgica, Chequia, Eslovenia, Francia, Italia, Lituania, Luxemburgo, Países Bajos, Portugal y Suecia. Y España representa a dieciocho Estados de la UE: Alemania, Austria, Bélgica, Chequia, Eslovaquia, Eslovenia, Estonia, Finlandia, Francia, Grecia, Italia, Letonia, Lituania, Luxemburgo, Malta, Países Bajos, Portugal, Suecia; además de representar a Suiza, perteneciente a la Asociación Europea de Libre Comercio.

El art. 8.1 no obliga, sino que faculta al Estado miembro a «aceptar» la representación de otro Estado miembro. Y el art. 8.5 dispone que los Estados miembros que no tengan consulado propio en un tercer Estado «procurarán» celebrar esos acuerdos con Estados que sí lo tengan. Según la información del MAEC, España nunca ha tenido problemas para encontrar Estados miembros que le representen ${ }^{58}$.

El texto de los acuerdos de representación analizados en este trabajo se ha solicitado a la Dirección General del MAEC competente por razón de la materia. Las características del contenido de esos acuerdos se fijan en el art. 8.4 del Código de Visados. En efecto, el contenido real de los acuerdos de representación de España es sencillo y se corresponde con el Código de Visados: se establecen los consulados o las demarcaciones de representación, y se determinan el alcance así como las condiciones del examen, expedición y

56 Reglamento (CE) núm. 810/2009 del Parlamento Europeo y del Consejo, de 13 de julio de 2009, por el que se establece un Código Comunitario sobre Visados (DO L 243, de 15 de septiembre de 2009, p. 1).

57 Véase la información a este respecto del sitio web del MAEC: http://www.exteriores. gob.es/Portal/es/ServiciosAlCiudadano/InformacionParaExtranjeros/Documents/ Lista $\% 20$ de $\% 20$ Representaciones $\% 20$ para $\% 201 a \% 20$ expedición $\% 20$ del $\% 20$ visado\%20uniforme.pdf

58 Subdirección General de Asuntos de Extranjería, unidad de la Dirección General de Españoles en el Exterior y de Asuntos Consulares y Migratorios. 
denegación de los visados ${ }^{59}$. No obstante, no se establecen en dicho art. 8.4 otras características formales de los acuerdos de representación - más que serán bilaterales, que entrarán en vigor y que podrán terminar- que pueden resultar importantes para su conformación y posterior calificación y tramitación en los órdenes nacionales.

Semejante indeterminación formal del Código de Visados ha permitido una práctica concertada de España desigual y disconforme con las nuevas disposiciones de la LTOAI en cuanto a la celebración, publicación y aplicación de estos acuerdos internacionales, como se verá en el punto $\mathrm{V}$ del trabajo.

\section{B. Acuerdos de colocación en delegaciones de la UE}

Los datos de la UE sobre los acuerdos de colocación entre el SEAE y los Estados miembros, expuestos en el Informe de Actividad Anual de 2014 ${ }^{60}$, son muy escasos y revelan una falta de transparencia que, como se ha dicho, también padece la práctica de España. Según el citado Informe, existen una cincuentena de casos de colocación entre las Administraciones Públicas de los Estados miembros ${ }^{61}$ y las ciento treinta y nueve delegaciones de la $\mathrm{UE}^{62}$. El primer caso de colocación sería el del Arreglo Administrativo, de 22 de mayo de 2012, entre el SEAE y Luxemburgo, para la instalación de la nueva

59 En relación con el acuerdo España-Suiza de 2011, el contenido de todos los acuerdos de representación de España es similar, se trate o no de Estados miembros de la UE.

60 2014 Annual Activity Report, European External Action Service, de 29 de abril de 2015, ref. Ares (2015) 1826113-29/04/2015, y disponible en: http://eeas.europa.eu/ background/docs/annual_activity_report_2014_en.pdf (consultado el 8.4.2016).

61 Los Estados que poseen acuerdos de colocación con el SEAE son dieciséis, por orden alfabético: Alemania, Austria, Croacia, Chequia, Dinamarca, Eslovaquia, España, Finlandia, Francia, Grecia, Lituania, Luxemburgo, Italia, Países Bajos, Portugal y el Reino Unido. Véase el trabajo basado en la información del SEAE de Sophie SCHNEIDER, European diplomacy through colocations between member State missions and EU delegations in third countries. Move towards one European Voice or Pragmatic Decision-Making?, master thesis, Erasmus University Rotterdam, 2015, p. 29.

62 De las ciento treinta y nueve delegaciones de la UE cabe distinguir lo siguiente: ciento tres son bilaterales con otro Estado; doce están en régimen de acreditación múltiple ante dos o más Estados; siete son delegaciones regionales responsables de otra delegación; cinco son delegaciones regionales dependientes de otra delegación; cuatro son oficinas de representación ante territorios como Cisjordania y Franja de Gaza, Hong Kong, Kosovo, Taiwán, y ocho son delegaciones ante organizaciones internacionales. Información disponible en el sitio web del SEAE: http://eeas.europa.eu. 
misión diplomática luxemburguesa en el complejo de la Delegación de la UE en Etiopía ${ }^{63}$.

Conforme a la Dirección General del Servicio Exterior del MAEC, las administraciones de España han celebrado, al menos, cuatro acuerdos de colocación. Primero, un MOU entre la Embajada de España y la Delegación de la UE en la República de Sudán, de fecha incierta, pues se comenzó a negociar en 2009 y el Consejo de Ministros autorizó su firma mediante acuerdo de 18 de diciembre de $2015^{64}$. Los firmantes son la Embajada de España y la Delegación de la UE, no el MAEC y el SEAE. El objeto del MOU es la regulación del uso de un espacio en los locales de la Delegación de la UE por el personal de la Embajada de España en Sudán, que tiene acreditación múltiple en Juba, capital del nuevo Estado de Sudán del Sur. Así, se estipula la superficie que ocupará la Embajada dentro del espacio conjunto, el pago por esta del uso, mantenimiento y renovación de los servicios comunes e instalaciones según un porcentaje, el contrato directo por la Embajada de los servicios de telefonía, agua, electricidad e internet, el respeto de las normas de seguridad y salud de la UE y la responsabilidad por daños causados por el personal de la Embajada o por sus visitantes. Además, se prevé la posible enmienda, terminación y suspensión del MOU.

Segundo, el MOU entre el MAEC y el SEAE ${ }^{65}$, de 10 de diciembre de 2012, relativo al espacio para oficinas y las instalaciones para el uso por la Embajada de España en Sana de los locales de la Delegación de la UE en Yemen. Se trata del primer acuerdo de este tipo, cuyo contenido es parecido al mencionado anteriormente respecto a la República de Sudán, si bien existe un mayor detalle en las disposiciones sobre el reembolso por España por el

63 Según la información del sitio web del SEAE: http://eeas.europa.eu/statements/local/20120524_ethiopia_en.pdf (consultado el 8.4.2016).

64 Consúltese la referencia del acuerdo del Consejo de Ministros en www.lamoncloa. gob.es, donde se explica el significado de la colocación, a partir de la institución del arrendamiento, de la siguiente manera: «Los Estados miembros y la UE han comenzado a colaborar con el objetivo de reestructurar su presencia en el exterior a través de la fórmula de la 'colocación', que consiste en que un Estado arrienda un espacio de oficina en un edificio de la Delegación de la UE. Ello permite un elevado ahorro económico frente al coste que supondría la apertura de una Embajada, a la vez que posibilita una presencia diplomática residente, reforzando la influencia de España ante ese país». Evidentemente, este tipo de colocación — así explicada— es sólo uno de los posibles, como demuestran otros acuerdos de España analizados.

65 Una vez en vigor la Decisión del Consejo de 26 de julio de 2010 por la que se establece la organización y el funcionamiento del SEAE (DO L 201, de 3 de agosto de 2010, p. 30). 
uso del espacio e instalaciones que la Delegación de la UE tiene arrendadas en Yemen. Destacan las disposiciones 10, 12 y 15, pues recogen, respectivamente, que el SEAE pondrá cuidado en la seguridad del personal de la Embajada de España cuando se encuentre en los locales, que la Embajada no representa ni compromete a la Delegación de la UE, legal ni financieramente y que el MOU no afecta a los privilegios e inmunidades de los signatarios. Ello demuestra el carácter jurídico internacional del MOU y que no contiene un simple contrato de subarrendamiento sometido al derecho privado.

Tercero, el MAEC y el SEAE firmaron el 18 de noviembre de 2013 un MOU relativo al espacio de oficinas e instalaciones para el uso de la Embajada de España en Turquía, acreditada en Azerbaiyán, en los locales de la Delegación de la UE. El contenido es casi idéntico al MOU referido al Yemen, pues contiene derechos y obligaciones de uso así como los costes al respecto ${ }^{66}$.

El cuarto caso es el del MOU entre el MAEC y el SEAE, de 10 de febrero de 2014, sobre el uso por la Embajada de España en Tailandia de los locales de la Delegación de la UE en Myanmar, muy parecido al anterior.

Como se ha comprobado, no existen colocaciones de España en delegaciones de la UE acreditadas en Estados con los que se tenga una relación diplomática muy intensa por su importancia política y económica, destacando en este aspecto, si acaso, Azerbaiyán. Estas colocaciones se han producido a partir del año 2012 y tienen sus precedentes en los acuerdos que, a continuación, se analizan entre España y los Estados miembros de la UE.

\section{Acuerdos de colocación en misiones diplomáticas de los Estados miembros}

De la documentación del MAEC se extraen cuatro casos, que se exponen por orden cronológico. Primero, el MOU entre el MAEC de España y el MAE de Malta para permitir a los funcionarios respectivos el uso de las instalaciones e infraestructura de las embajadas y consulados en terceros países del otro firmante, de 3 de julio de 2008. Se prevé cumplir el acuerdo mediante memorandos específicos sujetos a reciprocidad, que formarán parte integrante del MOU principal. Además, se regula el uso, dentro del espacio asignado al otro Estado, de la bandera y escudo nacionales; se estipula que el acceso a ese espacio de las autoridades del Estado receptor requiere del consentimiento del jefe de la misión; se establece la responsabilidad por daños y perjuicios de cada firmante acaecidos dentro de los locales de las misiones del otro Estado;

66 Ambos MOU constan en los acuerdos del Consejo de Ministros, de 18 de diciembre de 2015, sobre autorización de firma de cada MOU, disponible en: www.lamoncloa. gob.es. 
se compromete la garantía de la confidencialidad ante asuntos sensibles; se asumen los gastos respectivos derivados de la estancia de los funcionarios que se designen, y los firmantes se obligan a solicitar el consentimiento previo del Estado receptor para permitir al otro firmante el uso de sus misiones. Esta forma de cooperación diplomática sólo puede regirse por la Convención de 1961, que constituye el derecho internacional general ${ }^{67}$. Las disposiciones finales prevén la aplicación indefinida del acuerdo desde la firma, la resolución de divergencias de interpretación y aplicación mediante acuerdo y la posibilidad de modificación del instrumento.

Segundo, el 4 de septiembre de 2008, el MAEC de España y el MAE de Chipre firmaron un MOU casi idéntico al anterior con Malta. Y lo mismo sucede con el tercer MOU, entre el MAEC de España y el MAE de Portugal, de 22 de enero de 2009, al que se incorpora la obligación de los firmantes de la suscripción de seguros de responsabilidad civil por daños y perjuicios. Recientemente, parece haberse negociado un cuarto MOU similar a los anteriores entre el MAEC de España y el MAE de los Países Bajos, pero no consta la firma del texto. Evidentemente, la cooperación diplomática se entabla entre miembros de la UE y los años de mayor cooperación son el 2008 y 2009.

\section{Acuerdos de intercambio de diplomáticos en servicios centrales}

Se desprende de los datos obtenidos que, entre 2004 y 2010, el MAEC de España ha celebrado, por lo menos, cinco acuerdos para formalizar el intercambio de diplomáticos en los servicios centrales de los respectivos ministerios. Entre ellos pueden encontrarse similitudes y diferencias. El primero en el tiempo es el MOU entre el MAEC de España y el MAE de Bulgaria, de 9 de junio de 2005, cuyo objeto de cooperación diplomática es muy general, bajo la perspectiva de la adhesión de Bulgaria a la $\mathrm{UE}^{68}$ y de la formulación de la PESC, así como de las políticas europeas comunes. En ese contexto, se conciben mecanismos de consulta y coordinación que incluyen el intercambio regular de expertos y diplomáticos, que se colocarán en los servicios centrales

67 En efecto, su art. 12 dispone que el Estado acreditante no podrá sin el consentimiento previo y expreso del Estado receptor establecer oficinas que formen parte de la misión en localidades distintas de aquella en que radique la propia misión, y el art. 22 otorga una especial protección a esas oficinas y estipula que los locales de la misión son inviolables, con el objeto de permitir el libre ejercicio de las funciones propias de la representación diplomática.

68 Producida, como es bien sabido, el 1 de enero de 2007, fecha de entrada en vigor del Tratado de adhesión a la UE de Bulgaria y Rumanía. 
o en representaciones diplomáticas de los Estados implicados, con sujeción a acuerdos específicos. La aplicación del MOU será desde su firma.

El segundo caso es más específico, pues mediante el MOU entre el MAEC de España y el MAE de Eslovenia, de 24 de mayo de 2006, se acuerda el envío de dos diplomáticos eslovenos a la Dirección General para Iberoamérica del MAEC, durante un periodo determinado, para preparar la presidencia eslovena del Consejo de la UE en el primer semestre de 2008. En el texto del MOU se reconoce que su contenido no está amparado por el Convenio de 1961 y que se basa en «una relación de cortesía que no implica más compromisos que los que los ministerios quieran asumir». Además, se acuerda que el MAE esloveno asuma con cargo a su presupuesto anual ordinario todos los gastos derivados de esa estancia. Se prevé la posible modificación y la aplicación desde la firma.

El tercer instrumento se denomina Convención entre el MAEC de España y el MAE de Francia, y se firma el 5 de octubre de 2006. Su objeto es la colocación de un diplomático francés durante dos años, renovables, en una Dirección General del MAEC para ejercer funciones de consejero, sin implicar «una participación directa o indirecta en el ejercicio de poder público y en la salvaguarda de los intereses del Estado» ${ }^{69}$. Además, este diplomático estará sometido, junto a la Convención, a la normativa francesa sobre el estatuto de este tipo de funcionarios ${ }^{70}$.

El cuarto acuerdo es la Declaración conjunta del MAEC de España y el MAE de Alemania, de 10 de noviembre de 2006. En este instrumento se precisa, acertadamente, por comparación con los anteriores, y en línea con el Convenio de 1961, que «los funcionarios diplomáticos que participen en el intercambio serán acreditados como miembros de la misión diplomática que representa al Estado del Ministerio que envía en el país de acogida». Se estipula que los gastos del intercambio los sufragará el ministerio que envía, y

69 Esta salvaguarda parece responder al Real Decreto 543/2001, de 18 de mayo, por el que se regula el acceso al empleo público de la Administración General del Estado y sus organismos públicos de nacionales de otros Estados a los que es de aplicación el derecho a la libre circulación de trabajadores (BOE núm. 130, de 31 de mayo de 2001).

70 Decreto 69-222, de 6 de marzo de 1969, relativo al estatuto particular de los agentes diplomáticos y consulares, disponible en: https://www.legifrance.gouv.fr/affichTexte. do?cidTexte=JORFTEXT000000499400 (consultado el 8.4.2016). También, el Decreto 67-290 de 28 de marzo de 1967, por el que se fijan las modalidades de cálculo de los emolumentos del personal del Estado y entes públicos del Estado con carácter administrativo en servicio en el extranjero. 
se prevé la modificación de la Declaración Conjunta, que se aplicará desde su firma por un periodo de tres años, prorrogables tácitamente.

El quinto instrumento es el MOU entre el MAEC de España y el MAE de Polonia, de 16 de septiembre de 2010, para el intercambio de funcionarios diplomáticos, que responde a las características del acuerdo con Bulgaria. Sin embargo, en lo relativo a la protección de la información clasificada, se anexa una declaración de compromiso que deberán firmar los participantes, y que puede entenderse que posee carácter jurídico.

A pesar de esta práctica concertada de España, ya se ha afirmado que la LASE no la contempla en los arts. 49 y 52.

\section{EN LA COMUNIDAD IBEROAMERICANA DE NACIONES}

\section{A. Acuerdos de colocación entre Estados}

De las fuentes del MAEC se analizan seis acuerdos que pueden ordenarse en dos grupos. En el primero encajan tres acuerdos del MAEC de España con los MAE de Estados no iberoamericanos, que pretenden servirse de la experiencia diplomática española en Iberoamérica a través de la colocación en las misiones diplomáticas de España en México D. F., Buenos Aires y Santo Domingo. Por el orden cronológico de la firma, se trata del MOU entre el MAEC de España y el MAE de Letonia para el envío de un diplomático letón a la Embajada de España en México, de 3 de mayo de 2005. En su texto se reconoce que esta forma de cooperación «no se contempla en los Convenios de 1961 y de 1963", por lo que «se basa en una relación de mera cortesía que no genera más compromisos que los que las partes estén dispuestos a asumir». Sin embargo, cabe reiterar por nuestra parte que los citados Convenios de 1961 y de 1963 sí resultan aplicables con carácter general para regular varias cuestiones previstas en el MOU, como el estatuto de los locales de la misión y la autoridad del jefe de misión en materias de acceso y seguridad a dichos locales. El texto del MOU también se refiere al abono de los gastos comunes de forma proporcional; se incluye la responsabilidad letona por daños y perjuicios acaecidos en sus locales; las autoridades letonas se comprometen a mantener la confidencialidad de la información sensible para España, y se establece la necesidad de solicitar el consentimiento del Estado receptor para dicha colocación. Como puede apreciarse, este MOU, que es anterior a los acuerdos de colocación suscritos por España con los Estados miembros de la UE, fija unos patrones que luego se seguirán en los acuerdos europeos. En este mismo grupo se encuentra el MOU entre el MAEC de España y el MAE de Jordania, de 8 de febrero de 2007, sobre la cesión del uso de dependencias de la Embajada de España en Buenos Aires y de la Embajada de Jordania en 
Manama (Bahrein). A diferencia del anterior, el presente acuerdo no es unidireccional, sino que sirve para la colocación en las misiones diplomáticas de los dos Estados y se hace constante referencia a las normas pertinentes de la Convención de 1961 (arts. 20 y 22). Por lo demás, sus contenidos son similares. El tercer y último instrumento de este grupo ha sido mencionado en el punto I, con ocasión de la representación o protección de intereses. Efectivamente, el MOU y su Protocolo de aplicación entre el MAEC de España y el MAE de los Emiratos Árabes Unidos, de 29 de mayo de 2009, sobre representación diplomática no responde a la institución regulada en el art. 46 del Convenio de 1961, sino que es un acuerdo de colocación de un diplomático de los Emiratos en la Embajada de España en Santo Domingo, que así será acreditado ante la República Dominicana.

En el segundo grupo se encuentran tres acuerdos bilaterales de España con otros Estados de la Comunidad Iberoamericana. El 12 de junio de 2008 se firma el MOU entre el MAEC de España y el MAE de México para permitir el uso de las instalaciones e infraestructura de la Embajada de España en Abuja (Nigeria) por un diplomático mexicano. Su contenido es similar a los analizados anteriormente. El más reciente MOU, el existente entre el MAEC de España y el MAE de Colombia, de 8 de octubre de 2014, para permitir el uso de instalaciones e infraestructuras de las embajadas y consulados de los signatarios en terceros Estados, presenta algunas novedades. En uno de los considerandos se establece que los dos Estados son partes de los Convenios de 1961 y de 1963, lo que — en nuestra opinión — no afecta a las observaciones realizadas sobre que, si bien la colocación no se contempla en ellas, su aplicación práctica conlleva la intervención de alguna de sus disposiciones; $y$, por descontado, el MOU no puede caracterizarse como un acuerdo internacional administrativo o de aplicación de esos Convenios. La colocación se somete a la reciprocidad, dado que la colocación es bidireccional, y a la suscripción de un acuerdo específico. Se precisa que el MOU no implica la representación del Estado por los diplomáticos del otro Estado. El resto de disposiciones es similar a los casos analizados. El apartado undécimo también merece ser resaltado pues dispone que «la ejecución del presente MOU se sujeta a las legislaciones nacionales de las respectivas partes y del Estado receptor, y no acarreará obligaciones de derecho internacional para los Estados». Semejante disposición plantea el problema de la calificación de la naturaleza del MOU, que llevó a conclusiones diferentes a la Asesoría Jurídica Internacional y a la Abogacía General del Estado ${ }^{71}$, cuestión que será abordada en el siguiente

71 Dictamen de la Abogacía General del Estado ref. A. G. Asuntos Exteriores y Cooperación 4/14 (R-384/2014), de 26 de mayo de 2014. 
punto V. Finalmente, del mismo tenor es el MOU entre el MAEC de España y el MAE de Chile, firmado el 30 de octubre de 2014.

\section{B. Otros acuerdos de cooperación diplomática general que incluyen la colocación}

España, como Estado, celebró el 27 de junio de 1979 un tratado internacional con Colombia, denominado Acuerdo de Complementariedad y Apoyo Mutuo Diplomático ${ }^{72}$. Su contenido principal está en el art. 2, que prevé la utilización de los servicios de las misiones diplomáticas de la otra parte en terceros Estados «en los que una de las dos no disponga de una representación acreditada con carácter residente»; es decir, regula la posibilidad de la colocación y no comporta la representación del art. 46 del Convenio de $1961^{73}$. También, el art. 3 estipula que en aquellas capitales en que concurran misiones diplomáticas residentes de las dos partes contratantes, ambos Gobiernos podrán pedirse apoyo diplomático.

Pues bien, a la vista del vigente Acuerdo entre España y Colombia de 1979, de duración ilimitada, no se entiende la razón por la cual los dos Gobiernos sintieron la necesidad de concluir el MOU de 2014 que ha sido analizado anteriormente. En efecto, el último inciso del art. segundo del Acuerdo prevé la celebración de un canje de notas de aplicación de esa "complementariedad» diplomática. Además, cabe subrayar el origen iberoamericano para España de esta forma de diplomacia que, como se ha visto, se ha extendido al marco de la UE.

Dos tratados similares son el Acuerdo de Complementariedad y Apoyo Mutuo Diplomático entre España y Costa Rica, de 17 de abril de $1991^{74}$, y el Acuerdo de Complementariedad y Apoyo Mutuo Diplomático entre España y Honduras, de 15 de febrero de $1995^{75}$, ambos tramitados por la vía del art. 94.2 de la Constitución ${ }^{76}$. Precisamente, a continuación se analiza esta heterogeneidad en la naturaleza de los instrumentos de la práctica de España.

72 BOE núm. 56, de 6 de marzo de 1981, p. 4998.

73 Por la fecha de la firma, este tratado no pudo obtener el dictamen del todavía inexistente Consejo de Estado; sin embargo, fue autorizado por las Cortes sobre la base del art. 94.1, según consta en el instrumento de ratificación de 20 de octubre de 1980 y en el BOCG núm. 39, de 7 de marzo de 1980.

74 BOE núm. 104, de 2 de mayo de 1994, p. 13501.

75 BOE núm. 57, de 7 de marzo de 2002, p. 9340.

76 Véanse, respectivamente, los Dictámenes 815/1991, de 19 de septiembre de 1991, y 854/1995, de 18 de mayo de 1995, en los que el Consejo de Estado, de manera muy 


\section{CONCLUSIONES. PROPUESTAS DE ACUERDOS MODELO}

La práctica concertada de España se compone de más de cuarenta acuerdos relativos a variadas formas de cooperación diplomática y consular. A lo largo del trabajo se han manifiestado tres problemas que inciden en la concepción y en la calificación de la naturaleza de estos instrumentos: uno, la falta de publicidad oficial de la mayoría de estos acuerdos; otro, las diferentes formas de materialización de acuerdos de contenido similar; finalmente, la inadecuación del contenido con la naturaleza que se les ha dado. Puesto que se ha contado con el texto de un buen número de acuerdos, este trabajo propone unas soluciones a esos problemas.

La primera propuesta de mejora de la práctica de España es que los órganos que cuentan con el poder de iniciativa, o sea, Exteriores y Hacienda, mediante el informe del Consejo Ejecutivo de Política Exterior, deben concebir cada acuerdo sobre la base de las cuatro categorías operativas en el derecho español, atendiendo a la LTOAI y a la Ley 40/2015, de 1 de octubre, de Régimen Jurídico del Sector Público. Debe tenerse en cuenta que los arts. 49, 50 y 52 de la LASE dejan abierta esta cuestión de la forma y naturaleza de los acuerdos.

La segunda propuesta de solución afecta a los acuerdos prácticos de protección consular en el seno de la UE, que no se conocen públicamente y de los que el autor del trabajo no ha conseguido ninguno. Al estar previstos en la Directiva (UE) 2015/637, de 20 de abril de 2015, si tuvieran un contenido jurídico adaptado a este acto institucional, podrían ser concebidos como acuerdos internacionales administrativos, por analogía con lo previsto en los arts. 2.b y 38 a 42 de la LTOAI $^{77}$. Al tener un contenido jurídicamente relevante quedarían excluidos los acuerdos internacionales no normativos. En cualquier caso, los acuerdos prácticos deberían ser públicos y conocidos, por su finalidad y porque si tuvieran la naturaleza de acuerdos internacionales administrativos lo exigiría el art. 41 de la LTOAI. No debe desconsiderarse la posible aparición de un problema adicional, estando pendiente la transposición de la Directiva. En efecto, puede suceder que España y otros Estados miembros adopten determinadas disposiciones legales, reglamentarias y

discutible, entiende que los tratados encierran la institución de la representación de intereses, en virtud del art. 46 del Convenio de 1961.

77 Sobre la noción de acuerdos internacionales administrativos en la práctica de España y de la UE, véase, Antonio PASTOR PALOMAR, «De los acuerdos internacionales administrativos", en Comentarios a la Ley de Tratados y otros Acuerdos Internacionales, op. cit., nota 4, p. 791. 
administrativas, condicionadas por el derecho interno, que incidan en una calificación dispar de los acuerdos prácticos. Unos Estados pueden darles la naturaleza de acuerdos de derecho interno, mientras que otros la de acuerdos internacionales, ya sean tratados o acuerdos internacionales administrativos. Obviamente, esta situación debería evitarse en aras de conseguir la unidad de naturaleza y la efectiva aplicación del acuerdo.

En tercer lugar, debe corregirse la práctica relativa a los acuerdos de representación en materia de expedición de visados Schengen, que han dado lugar a una práctica heterogénea y camuflada en el entorno de la cooperación interadministrativa de índole consular. Se tiene constancia pública y oficial del Canje de Notas de 2010 entre España y Estonia, que pretendía adaptar el Acuerdo bilateral de 2009 al Código de Visados, así que se formalizó y tramitó como un tratado internacional del art. 94.2 de la Constitución ${ }^{78}$. Sin embargo, hasta la fecha de redacción de este trabajo, no ha habido otro acuerdo bilateral celebrado por España y concebido como constitutivo de tratado. Otros acuerdos de representación de España se han instrumentado en notas verbales, celebradas entre el MAEC y una embajada extranjera, o viceversa. La propuesta de este trabajo en relación con estos acuerdos, que tienen un contenido jurídico, significa que, por analogía con lo dispuesto en los arts. 2.b, y 38 a 42 de la LTOAI, estas notas verbales podrían concebirse como acuerdos internacionales administrativos celebrados en ejecución del Código de Visados de 2009, a condición de que estuvieran cubiertas material y formalmente por este. Como es sabido, el procedimiento de celebración sería simplemente el del informe de Exteriores, la firma,y la posterior toma de conocimiento por el Consejo de Ministros. El contenido de los acuerdos vendría determinado por el citado Código de Visados.

En cuarto lugar, respecto a los acuerdos de colocación entre el MAEC y el SEAE, cabe concluir que su celebración y tramitación en España es la adecuada, por lo que debe mantenerse en el estado actual. De hecho, se han celebrado y tramitado como acuerdos internacionales administrativos, por su

78 Canje de Notas constitutivo de Acuerdo por el que se enmienda el Acuerdo entre el Reino de España y la República de Estonia para la representación en la expedición de visados Schengen, de 11 de febrero de 2009, de 25 de marzo y 14 de mayo de 2010 (BOE núm. 153, de 24 de junio de 2010, p. 55.022; BOE núm. 243, de 7 de octubre de 2010, p. 84802). Véanse, el Dictamen del Consejo de Estado 282/2009, de 5 de marzo, y el Dictamen del Consejo de Estado 478/2010, de 22 de abril, en los que el órgano consultivo entiende que ni el Acuerdo de 2009 ni su enmienda mediante el Canje de Notas de 2010 se subsumen en los supuestos del art. 94.1 de la Constitución, por lo que, de conformidad con el art. 94.2, no se requiere para su celebración la autorización previa de las Cortes. 
contenido, y en razón de su cobertura en la Decisión del Consejo de 2010 por la que se establece la organización y el funcionamiento del SEAE. Sin embargo, hay puntos de mejora, pues según la LTOAI, una vez firmado el acuerdo, éste será elevado al Consejo de Ministros para toma de conocimiento. Por consiguiente, este acuerdo del Consejo de Ministros no debe ser de autorización de firma, como refleja su reunión del 18 de diciembre de 2015. Por otro lado, en la tramitación también debe aplicarse el art. 49.1 de la LASE, que exige el previo informe del Consejo Ejecutivo de Política Exterior, y la iniciativa conjunta del MAEC y del Ministerio de Hacienda. Además, el hecho de que la delegación de la UE tenga sus locales arrendados en un tercer Estado y subarriende a España el uso de sus instalaciones, no debe incidir en la consideración del acuerdo como de derecho privado, porque la última capa de las obligaciones de los firmantes es de naturaleza internacional.

En quinto lugar, a diferencia de los anteriores, que están condicionados por la particularidad del derecho de la UE, los acuerdos de colocación interestatales, ya sea entre Estados miembros o entre Estados iberoamericanos, se han instrumentado en acuerdos internacionales no normativos, o MOU. Esta práctica no ha causado problemas hasta el momento, pero cabe mejorarla técnicamente y proponer un cambio, para evitar la inadecuación que implica la firma de un MOU con obligaciones esencialmente jurídicas, como son las que disponen una responsabilidad del Estado por daños y perjuicios, o la garantía de la confidencialidad de la información. Puesto que estos acuerdos están previstos en el art. 49.1 e), 50 y 52 de la LASE, cabría suscribirlos como acuerdos interadministrativos de Derecho interno, siempre que lo admita el otro firmante, requiriendo en España la sencilla tramitación incluida en dichas disposiciones. La LASE sustituye a la Ley 33/2003, de 3 de noviembre, del Patrimonio de las Administraciones Públicas, en el entendido de que el local diplomático compartido sea de propiedad del Estado español pues, esta ley sencillamente no es de aplicación en estos supuestos de cooperación internacional que comportan una decisión de acción exterior; no es un problema puramente patrimonial ${ }^{79}$. Si hubiera un tratado de cobertura con previsiones de ejecución mediante otros acuerdos, como los acuerdos de complementariedad de España con Colombia, Honduras y Costa Rica, esos acuerdos de

79 En contra de lo manifestado en el Dictamen de la Abogacía General del Estado, ref. A. G Asuntos Exteriores y Cooperación 4/14 (R-384/2014), de 26 de mayo de 2014, que encajó el supuesto en el art. 90 de dicha Ley 33/2003 (LPAP), y que caracterizó el MOU entre el MAEC de España y el MAE de Colombia como un contrato del art. 4.1.f del Texto Refundido de la Ley de Contratos del Sector Público. 
ejecución podrían ser acuerdos internacionales administrativos, conforme a la LTOAI.

Por último, los acuerdos de intercambio de diplomáticos en los servicios centrales de Exteriores no están contemplados en las citadas disposiciones de la LASE, por lo que en su concepción y redacción hay que buscar otra base que incida en su naturaleza, y no puede ser otra que la del art. 97 de la Constitución sobre la dirección de la política exterior por el Gobierno, como reconoce y concreta el art. 6 de la LASE. El estudio de los acuerdos del MAEC de España ha demostrado que pueden constituirse en puros acuerdos internacionales no normativos. No obstante, también cabe entender que estos acuerdos responden a los mismos principios que los acuerdos de colocación, a los que sí les resultan aplicables las otras disposiciones de la LASE y, de esta manera, si se pretendiera incluir cláusulas con contenido jurídico, se podría argumentar que los acuerdos se fundan en el derecho interno, en tanto que acuerdos interadministrativos.

Ha podido comprobarse que la regulación de la LASE es, a la vez, novedosa, deficiente e insuficiente, causando problemas de interpretación a los órganos consultivos del Estado. Se echa en falta su vocación ordenadora de la actividad de la Administración del Estado en la materia pero, por lo menos, recoge varios supuestos de la práctica y presenta unos principios procedimentales y materiales que son comunes al uso compartido de embajadas y consulados. 